\title{
EVALUASI PRO KONTRA TRANSPORTASI ONLINE
}

\author{
Oleh \\ Ari Gusnita, S.A.N.,M.Si. \\ STISIPOL Dharma Wacana Metro \\ Email : ari.gusnitadw@gmail.com
}

\begin{abstract}
ABSTRAK
Transformasi penggunaan transportasi konvensional yang bermetamorfosa ke transportasi online merupakan hal yang tidak bisa terhindarkan di era digital. Namun, perkembangan teknologi komunikasi melalui transportasi online menjadi persoalan serius di Indonesia. Seiring bergejolaknya penolakan dari pelaku transportasi konvensional di sejumlah daerah maupun aturan yang membuat membuat pelaku transportasi kovenvensional menjadi merasa tidak mendapat keadilan dalam mencari rejeki. Hal lainnya seperti juga terkait aturan-aturan yang bisa dikatakan belum mencapai maksimal terkait pengimplementasiannya. Pasca putusan Mahkamah Agung RI yang menganulir Peraturan Menteri Perhubungan PM 26 Tahun 2017 tentang Penyelenggaraan Angkutan Orang Dengan Kendaraan Bermotor Umum Tidak Dalam Trayek (PM 26), praktis Indonesia tidak memiliki aturan yang mengatur hubungan dan keselarasan antara transportasi online dengan transportasi konvensional. Pemerintah ada baiknya menghadapi era digital dengan membuat aturan yang tegas sehingga tidak terlihat seperti tidak tegas. Hal itu dilihat dari pembatalan sejumlah pasal dalam Peraturan Menteri Perhubungan Nomor 26 Tahun 2017 tentang Penyelenggaraan Angkutan Orang dengan Kendaraan Bermotor Umum Tidak Dalam Trayek oleh Mahkamah Agung (MA), hal ini guna menghindari pro kontra. Dengan melihat pro kontra yang terjadi pada masalah transportasi online yang ada di Indonesia saat ini, perlu dilakukannya evaluasi baik dari undang-undang atau aturan resmi yang pemerintah buat, maupun dari ketegasan pemerintah terkait peraturan dan pengimplementasian aturan tersebut. Hal lain yang menarik juga ialah masalah evaluasi dari kinerja pemerintah itu sendiri terkait sosialisasi, pendekatan kepada masayarakat sebagai pekerja transportasi konvensional dan pencegahan kerusuhan dimasa yang akan datang. Sehingga diharapkan dengan majunya teknologi diiringi juga dengan perkembangan Sumber Daya Manusia (SDM) baik pemerintah maupun masyaraktnya.
\end{abstract}

Kata Kunci: Evaluasi, Teknologi Komunikasi, Transportasi Online 


\section{LATAR BELAKANG}

Teknologi komunikasi yang semakin maju membawa perubahan dan kemajuan dalam perilaku penggunaan transportasi online melalui sistem aplikasi dan sistem informasi. Kehadiran teknologi aplikasi di smartphone berbasis sistem operasi Andriod, Windows membawa perubahan signifikan di segala bidang, tak terkecuali transportasi. Masyarakat sebagai konsumen diberikan kemudahan untuk memesan tiket pesawat terbang, kereta api, kapal laut dan jenis moda transportasi lain hanya dari gadget yang dimiliki. Konsumen tidak harus mengantri di bandara, stasiun, pelabuhan atau terminal hanya untuk mendapatkan tiket. Cukup dengan pencet gadget, tiket sudah dapat dipesan.

Tidak hanya berhenti pada sistem pemesanan tiket, teknologi aplikasi smartphone telah mampu menjawab kebutuhan masyarakat luas akan kemudahan mengakses transportasi. Dengan sekali klik, moda transportasi yang dipilih konsumen (sepeda motor atau mobil) hadir di depan pintu konsumen lengkap dengan data diri pengemudi, nomor kendaraan dan nomor telepon. Konsumen juga diberi panduan perjalanan hingga ke tujuan dengan fasilitas GPS (Global Positioning System). Bahkan aplikasi ini sudah dilengkapi informasi tarif yang harus dibayar konsumen sebelum memulai perjalanan. Hal ini sungguh sangat memudahkan konsumen untuk melakukan perjalanan.

Dengan kemudahan yang ditawarkan oleh aplikasi inilah yang membuat semakin eksis dan disukai konsumen di banyak kota besar. Ini nampak dari makin banyaknya konsumen yang mengunduh aplikasi untuk transportasi (transportasi online). Operator penyedia jasa layanan transportasi online juga terus bertumbuh. Di Jakarta, operator penyedia jasa layanan transportasi online dikuasai oleh tiga nama besar, yaitu; Gojek, Grab, Uber. Kendati tidak sebanyak tiga nama sebelumnya, ada juga nama-nama seperti My Blue Bird, Blue jek dan Lady jek yang turut meramaikan transportasi online di Jakarta.

Akan tetapi kehadiran transportasi online tidak luput dari permasalahan dan perdebatan. Pro kontra pendapat terus disuarakan lewat berbagai media. Baik yang secara langsung maupun tidak. Kelompok yang mendukung beranggapan bahwa transportai online menghadirkan terobosan baru yang mampu membuat perubahan dalam bertransportasi. Khususnya dalam hal kemudahan akses, tarif, kecepatan respon 
serta dianggap lebih nyaman dan aman. Bagi yang kubu kontra, kehadiran transportasi online dianggap sebagai pemicu kecemburuan sosial transportasi konvensional seperti ojek pangkalan, taksi maupun angkutan umum lainnya.Transportasi online dianggap ilegal karena tidak mengantongi izin seperti transportasi pada umummnya. Hal tersebut mengakibatkan munculnya aksi-aksi penolakan dan mogok yang dilakukan oleh awak transportasi konvensional. Seperti halnya di Jakarta protes penolakan pernah terjadi dengan aksi mogok masal oleh awak transportasi konvensional pada Maret 2016. Paguyuban Pengendara Angkutan Darat mengklaim aksi tersebut diikuti oleh lebih dari 15.000 angkutan konvensional seperti taksi, metromini, angkot dan lainnya.

Akan tetapi dukungan terhadap kehadiran transportasi online juga tak kalah ramai, kendati tidak dilakukan dengan cara turun ke jalan. Semakin banyak masyarakat yang mengunduh aplikasi transportasi online, baik dari android, windows maupun ios, menjadi salah satu bukti bahwa kehadirannya juga mendapat dukungan dan diterima oleh konsumen. Hal ini tentu menunjukan betapa masyarakat luas menerima kemajuan teknologi yang satu ini.
Permasalahnnya adalah apakah benar kehadiran transprotasi online sejalan dengan keinginan masyarakat? Bagaimana masyarakat menilai kehadiran transportasi online dari sudut pandang sebagai konsumen? Kemudian apa jaminan keamanan yang pemerintah berikan dalam hal transportasi online ini?. Hal lain adalah jelas evaluasi dari undang-undang atau aturan yang pemerintah terbitkan.

Seperti halnya undang-undang yang di buat oleh pemerintah terkait transportasi maupun lalu lintas dan angkutan umum, yakni UU No 22 Tahun 2009 tentang Lalu Lintas dan Angkutan Jalan yang mengatur tentang tata cara berlalu lintas, mengatur asas-asas dalam kendaraan dan bertransportasi. Sedangkan dalam Peraturan Menteri Perhubungan Nomor 26 tahun 2017 tentang Penyelenggaraan Angkutan Orang dengan Kendaraan Bermotor Umum Tidak Dalam Trayek (PM 26) sudah sesuai dengan peraturan yang ada. ssPutusan MA bernomor 37 P/HUM/2017 ini memutuskan angkutan sewa khusus berbasis aplikasi daring sebagai konsekuensi logis dari perkembangan teknologi dalam moda transportasi yang menawarkan pelayanan yang lebih baik, jaminan keamanan, dan 
perjalanan dengan harga yang relatif lebih murah dan tepat waktu

\section{TINJAUAN TEORI}

Kebijakan publik merupakan keputusan yang diambil atau tidak diambil oleh pemerintah guna menyelesaikan masalah publik. Evaluasi kebijakan adalah kegiatan yang menyangkut estimasi atau penilaian kebijakan yang mencakup substansi, implementasi dan dampak (Anderson: 1975). Evaluasi kebijakan dipandang sebagai suatu kegiatan fungsional. Artinya, evaluasi kebijakan tidak hanya dilakukan pada tahap akhir saja melainkan kepada seluruh proses kebijakan.

Menurut $W$. Dunn, istilah evaluasi mempunyai arti yang berhubungan, masingmasing menunjuk pada aplikasi beberapa skala nilai terhadap hasil kebijakan dan program. Evaluasi mencakup kesimpulan kemudian klarifikasi, kritik, penyesuaian dan perumusan masalah kembali sehingga terbentuk penilaian atau yang disebut evaluasi.

1). Analisis Kebijakan Menurut Lester dan Stewart, evaluasi kebijakan dapat dibedakan ke dalam dua tugas yang berbeda :

a. Untuk menentukan akibat apa yang ditimbulkan oleh suatu kebijakan dengan cara menggambarkan dampaknya dari kebijakan tersebut.

b. Untuk menilai keberhasilan atau kegagalan dari suatu kebijakan. Hal ini berdasarkan standar atau kriteria yang telah ditetapkan sebelumnya dan melihat efektivitas dari suatu program.

2). Tipe Dalam evaluasi kebijakan Publik adalah sebagai berikut :

Tipe evaluasi menurut James Anderson adalah sebagai berikut:

a. Evaluasi kebijakan dipahami sebagai kegiatan fungsional. Menyangkut prihal kepentingan (interest) dan ideologi dari suatu kebijakan.

b. Evaluasi yang memfokuskan diri pada bekerjanya kebijakan atau program kebijakan tertentu.

c. Evaluasi kebijakan sistematis. Melihat secara obyektif program-program kebijakan yang dijalankan untuk mengukur dampaknya bagi masyarakat dan melihat sejauh mana tujuan-tujuan yang telah dinyatakan tersebut dicapai. Menjawab kontribusi dampak dalam menjawab kebutuhan masyarakat. 
3) Langkah-Langkah Dalam Evaluasi

Menurut Edward A. Schuman mengemukakan 6 langkah dalam evaluasi kebijakan, yaitu:

a. Mengidentifikasi tujuan program yang akan dievaluasi

b. Analisis terhadap masalah

c. Deskripsi dan Standarisasi kegiatan

d. Pengukuran terhadap tingkatan perubahan yang terjadi

e. Menentukan apakah perubahan yang diamati merupakan akibat dari kegiatan tersebut atau

karena penyebab yang lain.

f. Beberapa indikator untuk menentukan keberadaan suatu dampak.

Keenam langkah diatas merupakan langkah-langkah yang diambil untuk menilai mulai dari tahap perencanaan sampai dengan dampak dari suatu kebijakan. Oleh sebab itu Edward mengungkapkan langkah-langkah evaluasi yang diambil dari suatu kebiajkan publik

4) Evaluasi dalam Analisis Kebijakan

Dalam melihat sifat evaluasi kebijakan publi, ada beberapa yang perlu diperhatikan yakni beberapa hal: a. Fokus nilai

b. Interdependensi fakta-Nilai, pemantauan : prasyarat

c Orientasi masa kini dan masa yang sudah lalu/ lampau

d Dualitas nilai (tujuan atau cara)

5. Fungsi Evaluasi Kebijakan Publik

Adapun fungsi-fungsi dari kita melakukan evaluasi publik adalah sebagai berikut. Pertama, dan yang paling penting, evaluasi memberi informasi yang valid dan dapat dipercaya mengenai kinerja kebijakan, yaitu, seberapa jauh kebutuhan, nilai dan kesempatan telah dapat dicapai melalui tindakan publik. Dalam hal ini, evaluasi mengungkapkan seberapa jauh tujuan-tujuan tertentu (misalnya, perbaikan kesehatan) dan target tertentu. Kedua, evaluasi memberi sumbangan pada klarifikasi dan kritik terhadap nilai-nilai yang mendasari pemilihan tujuan dan target. Nilai diperjelas dengan mendefinisikan dan mengoperasikan tujuan dan target. Nilai juga dikritik dengan menanyakan secara sistematis kepantasan tujuan dan target dalam hubungan dengan masalah yang dituju. Dalam menanyakan kepantasan tujuan dan sasaran, analis dapat menguji alternatif.sumber nilai maupun landasan mereka dalam berbagai bentuk rasionalitas (teknis, ekonomis, legal, sosial, substantif). Ketiga, evaluasi memberi 
sumbangan pada aplikasi metode-metode analisis kebijakan lainnya, termasuk perumusan masalah dan rekomendasi. Informasi tentang tidak memadainya kinerja kebijakan dapat memberi sumbangan pada perumusan ulang masalah kebijakan, sebagai contoh, dengan menunjukkan bahwa tujuan dan target perlu didefinisikan ulang. Evaluasi dapat pula menyumbang pada definisi alternatif kebijakan yang baru atau revisi kebijakan dengan menunjukkan bahwa alternatif kebijakan yang diunggulkan sebelumnya perlu dihapus dan diganti dengan yang lain.

\section{PEMBAHASAN}

\section{A. Konsep Evaluasi Kebijakan dan Transportasi Online}

Kebijakan publik merupakan sebuah tindakan yang ditimbulkan atas permasalahan yang ada di masyarakat. Kebijakan publik juga menimbulkan suatu konsekuensi atau dampak yang merupakan perubahan kondisi fisik maupun sosial akibat output dari kebijakan. Tak jarang juga kebijakan publik dibuat berdasarkan tujuan untuk memenuhi tuntutan aktor kebijakan. Hanya saja, karena alasan politik, tujuan kebijakan sering dirumuskan secara kabur dan tidak transparansi. Tidak jarang juga kebijakan publik dilakukan hanya karena rutinitas saja seperti rutinitas tahunan dan lain sebagainya sehingga kebijakan publik hanya dianggap progam rutinitas. Sehingga suatu kebijakan sering dibuat untuk mencapai maksud dan kepentingan yang berbeda dengan apa yang dirumuskan. Tidak jarang tindakan kebijakan yang telah diambil dan dibuat sedemikian rupa tidak dapat mewujudkan kebijakan. Hal tersebut mungkin disebabkan oleh lemahnya daya antisipasi para pembuat kebijakan maupun pendesain program dan proyek, terganggunya implementasi oleh kondisi lingkungan yang tidak dipikirkan sebelumnya. Oleh karena itu, untuk kepentingan inilah evaluasi kebijakan dilakukan oleh pemerintah.

Dalam kebijakan publik pelaksanaan evaluasi ini dalam beberapa hal mirip dengan pengawasan dan kontrol. Pelaku utamanya jelas pemerintah, akan tetapi sering pelaku yang lain seperti lembaga penelitian yang independen, partai politik, dan tokoh-tokoh masyarakat. Evaluasi tersebut tidak hanya terjadi pada saat akhir saja, tetapi pada setiap proses, baik formulasi maupun implementasi. Evaluasi kebijakan merupakan aktivitas ilmiah yang 
perlu dilakukan oleh para pengambil kebijakan di dalam tubuh birokrasi pemerintah maupun organisasi sosial dan politik. Di tangan aktor kebijakan ini, evaluasi memiliki fungsi yang sangat penting, yaitu memberikan masukan bagi penyempurnaan kebijakan. Dengan melakukan evaluasi, pemerintah dapat meningkatkan efektivitas program-program mereka sehingga meningkat pula kepuasan publik terhadap kebijakan pemerintah. Kemudian, hasil evaluasi tersebut dapat digunakan untuk memperkuat argumentasi agar pemerintah melakukan perbaikan terhadap kebijakannya sehingga asas keadilan, kemerataan, dan demokrasi lebih diperhatikan oleh pemerintah. Sepertinya kebijakan pemerintah yang dalam hal ini dikeluarkan oleh Kementerian Perhubungan terkait transportasi online contohnya. Peraturan ini menyangkut aturan-aturan dalam hal transportasi online.

Kehadiran transportasi online tidak terlepas dari perdebatan. Pro dan kontra pendapat terus disuarakan lewat berbagai media baik media sosial media visual maupun media cetak. Kelompok yang mendukung beranggapan bahwa transportai online menghadirkan inovasi baru yang mampu membuat perubahan dalam bertransportasi. Khususnya dalam hal kemudahan akses, kemudian tarif, kecepatan respon serta dianggap lebih nyaman dan aman. Bagi yang yang sebagian kontra, kehadiran transportasi online dituding sebagai pemicu kecemburuan sosial transportasi konvensional seperti ojek pangkalan, taksi maupun angkutan umum. Transportasi online dituding ilegal karena tidak mengantongi ijin-ijin seperti layaknya transportasi pada umumnya

Ujung dari masalah transportasi online adalah dengan munculnya aksi-aksi penolakan dan mogok yang dilakukan oleh awak transportasi konvensional. Contohnya di Jakarta protes penolakan pernah terjadi dengan aksi mogok masal oleh awak transportasi konvensional pada bulan Maret tahun 2016. Paguyuban Pengendara Angkutan Darat (PPAD) seperti angkutan konvensional seperti taksi, metromini, kopaja, bajaj, dan angkot. Akan tetapi dukungan terhadap kehadiran transportasi online juga tak kalah ramai, walaupun tidak dilakukan dengan cara turun ke jalan. Semakin banyak masyarakat yang mengunduh aplikasi transportasi online, baik dari android, windows maupun ios, menjadi salah satu bukti bahwa kehadirannya juga 
mendapat dukungan dan diterima oleh masyarakat luas.

Data lain yang menunjukan dukungan dan penerimaan dari masyarakat luas adalah dari YLKI telah melakukan survei secara online kepada konsumen transportasi online. Survei yang dilakukan pada 5-16 April 2017, melibatkan 4.668 (empat ribu enam ratus enam puluh delapan) responden. Survei menggunakan metodologi deskriptif dengan design study cross sectional yaitu; untuk melihat potret layanan angkutan umum berbasis aplikasi teknologi informasi pada satu waktu tertentu dengan menyebarkan angket berupa kuesioner dalam bentuk online.

Dari 4.668 responden, sebanyak 55 persen merupakan konsumen laki-laki, dan 45 persen adalah konsumen perempuan. Jika dilihat usia responden, paling banyak responden berusia 26-35 tahun (37 persen), disusul usia 36-45 tahun (23,6 persen), dan ketiga usia 17-25 tahun sssebanyak 23, 1 persen. Sedangkan secara berurutan responden rentang usia 46 - 55 sebanyak 11,3 persen, usia 56 - 65 (43 persen), dan di atas 65 ( 0,7 persen). Dengan demikian, responden survei didominasi oleh usia kerja atau dengan kata lain bahwa kehadiran transportasi online banyak dimanfaatkan oleh mereka yang berusia produktif. sebanyak 55 persen menggunakan transportasi online jenis mobil dan motor; sedangkan yang hanya menggunakan jasa motor sebanyak 21 persen dan menggunakan mobil saja sebanyak 24 persen. Artinya, mayoritas konsumen tidak hanya terpaku pada satu moda saja untuk menunjang aktivitasnya melalui transportasi online. Moda transportasi yang dipilih konsumen disesuaikan dengan kebutuhan. Sedangkan alasan konsumen memilih atau menggunakan transportasi online, secara umum beranggapan bahwa transportasi online lebih murah (84,1 persen), dan lebih cepat (81, 9 persen). Seperti terlihat di diagram 1. (sumber: www)

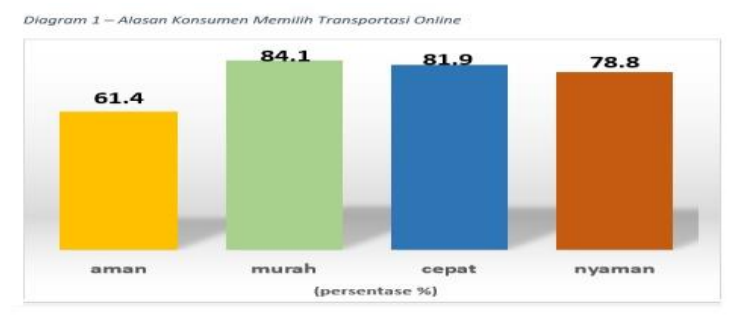

Sumber : http//ypki.or.id. Tahun 2017

Dari diagram tersebut terlihat bahwa faktor harga menjadi pertimbangan mayoritas konsumen. Responden beranggapan transportasi online lebih murah jika disandingkan dengan tarif moda transportasi konvensional. Di urutan kedua, 
konsumen memilih transportasi online karena dianggap lebih cepat. Namun dalam survei ini tidak mengelaborasi lebih dalam, yang dimaksud adalah lebih cepat ditemukan/ diakses (accessible) atau lebih cepat mencapai tujuan. Jika dilihat frekwensi penggunaannya, konsumen paling banyak menggunakan transportasi online adalah 2-3 kali dalam seminggu (31,6 persen), 1-2 kali dalam sehari (27,6 persen), seminggu sekali 13,7 persen dan lebih dari 3 kali dalam sehari sebanyak 8,7 persen. Anggapan konsumen dan frekwensi penggunaan tersebut sejalan dengan pendapat konsumen yang menilai tingkat pelayanan transportasi online sangat baik (77,7 persen) dan hanya 0,4 persen yang menyatakan kurang baik. Dominannya pendapat konsumen yang menilai positif pelayanan jasa transportasi online, nampaknya tidak serta merta menghapus kekecewaan konsumen. Sebab, ketika ditanyakan apakah konsumen pernah dikecewakan oleh pelayanannya; sebanyak 41 persen konsumen mengaku pernah, dan sebaliknya 59 persen konsumen menjawab tidak/ belum pernah dikecewakan. (sumber : http://ypki.or.id)

Dari data dan uraian tersebut diatas evaluasi dari perkembangan teknologi menuai mode transportasi yang banyak disukai masyarakat luas. Ada berbagai alasan mengapa masyarakat menjadi sangat antusias menerima pembaruan teknologi dari sisi transportasi online ini baik kendaraan beroda dua maupun beroda empat. Kenyamanan menjadi pilihan utama oleh sebagian besar masayarakat sehingga pemilihan transportasi online menjadi banyak minati.

\section{B. Evaluasi Dasar Hukum Transportasi Online \\ 1) Peraturan Menteri Perhubungan No. 32 Tahun 2016}

Adapun landasan yang digunakan untuk penerbitan Permenhub 32 Tahun 2016 ini adalah UU Lalu Lintas No 22 Tahun 2009. Dalam Permenhub 32 Tahun 2016 ini juga mengatur, perusahaan angkutan umum tidak dalam trayek wajib mempunyai izin yang dikenakan PNBP, perusahaan harus berbadan hukum Indonesia.

Adapun untuk memperoleh izin adalah, minimal memiliki 5 kendaraan yang dibutikan dengan STNK atas nama perusahaan, memiliki pool, memiliki fasilitas perawatan kendaraan yang 
dibuktikan dengan dokumen kepemilikan atau perjanjian kerjasama dengan pihak lain, memperkerjakan pengemudi dengan SIM Umum sesuai dengan golongan kendaraan serta persyaratan administrasi lainnya berupa akte pendirian, bukti pengesahan sebagai badan hukum.

Dalam operasionalnya, perusahaan angkutan umum dapat mengunakan aplikasi berbasis teknologi informasi baik yang dilakukan secara mandiri atau bekerjasama dengan perusahaan penyedia jasa aplikasi yang berbadan hukum. Perusahaan penyedia jasa aplikasi informasi yang memberikan layanan reservasi ankutan umum, harus bekerjasama dengan perusahaan angkutan umum yang telah memiliki izin penyelenggara angkutan, dilarang sebagai penyelenggara angkutan umum seperti menetapkan tarif dan memungut bayaran, merekrut pegemudi dan mementukan besaran penghasilan pengemudi.. Dalam rangka mengawasan perusahaan penyedia aplikasi harus melaporkan profil perusahaan, memberikan akses monitoring operasaional pelayanan, data perusahaan yang bekerjasama, data kendaraan dan pengemudi serta layanan pelanggan berupa nomor telpon, email dan alamat perusahaan kepada Dirjen Perhubungan Darat.
2) Peraturan Menteri Perhubungan No. 26 Tahun 2017

Setelah terbitnya Permen yakni Kementerian Perhubungan Nomor 32 Tahun 2016 maka kemudian Kementerian Perhubungan kembali menetapkan Peraturan Menteri Perhubungan Nomor PM 26 Tahun 2017 pada 1 April 2017 sebagai revisi Peraturan Menteri Perhubungan Nomor PM 32 Tahun 2016 tentang Penyelenggaraan Angkutan Orang Dengan Kendaraan Bermotor Umum Tidak Dalam Trayek. Dalam pemberlakuan aturan tersebut, Menteri Perhubungan menegaskan akan dilakukan dengan masa transisi bagi implementasi pasal-pasal yang akan dilakukan bertahap.

PM 26 tahun 2017 tersebut diantaranya memuat 11 poin revisi yang telah dibahas dan disepakati bersama antara para pemangku kepentingan, seperti para akademisi, pengamat transportasi, asosiasi terkait, dan pelaku usaha jasa transportasi, baik yang reguler maupun yang berbasis aplikasi (online). Hasilnya selain sudah dilakukan uji publik juga telah disosialisasikan ke berbagai kota dan dipublikasikan melalui media massa. Peraturan Menteri tersebut berlaku sejak ditetapkan atau 1 April 2017 namun ada 
beberapa substansi materi yang memerlukan masa transisi dalam penerapannya.

Dari 11 poin revisi aturan tersebut, 4 poin diberlakukan secara langsung pada 1 April 2017 yaitu diantaranya: (1) penetapan angkutan online sebagai angkutan sewa khusus, (2) persyaratan kapasitas silinder mesin kendaraan minimal $1.000 \mathrm{CC}$, (3) persyaratan keharusan memiliki tempat penyimpanan kendaraan, dan (4) kepemilikan atau kerjasama dengan bengkel yang merawat kendaraan,

3. Peraturan Menteri Perhubungan Nomor 108 Tahun 2017

Peraturan Kementerian Perhubungan Nomor 108 Tahun 2017 telah diterbitkan oleh Kementerian Perhubungan. Salah satu hal yang diatur dalam peraturan ini yakni operasional angkutan sewa khusus/online atau biasa disebut taksi online. PM 108 Tahun 2017 yang ditetapkan pada 1 November 2017 dan berlaku pada 1 Februari 2018 yang mengatur tentang penyelenggaraan Angkutan Orang dengan Kendaraan Bermotor Umum Tidak Dalam Trayek, yakni angkutan dalam wilayah perkotaan dan/atau kawasan tertentu, atau dari suatu tempat ke tempat lain, mempunyai asal dan tujuan tetapi tidak mempunyai lintasan dan waktu tetap. Beberapa jenis angkutan yang termasuk dalam kategori di atas yaitu taksi, angkutan pariwisata, angkutan karyawan, angkutan sewa, angkutan permukiman, dan angkutan sewa khusus dengan penggunaan aplikasi berbasis teknologi informasi.

Terdapat 9 poin revisi, yakni 1) argometer, 2) tarif, 3) wilayah operasi, 4) kuota atau perencanaan kebutuhan, 5) persyaratan minimal 5 kendaraan, 6) bukti kepemilikan kendaraan bermotor, 7) domisili TNKB, 8) Sertifikat Registrasi Uji Tipe (SRUT), dan 9) peran aplikator.

Ada beberapa hal yang mendasari dibuatnya PM 108 Tahun 2017, selain untuk mengakomodasi kemudahan aksesibilitas bagi masyarakat, Pemerintah harus memastikan pelayanan angkutan orang yang ada saat ini selamat, aman, nyaman, tertib, lancar, dan terjangkau. Dalam kaitannya dengan iklim usaha, peraturan ini untuk mendorong pertumbuhan perekonomian nasional berdasarkan demokrasi ekonomi yang berkeadilan dan prinsip pemberdayaan usaha mikro, kecil, dan menengah. Bagaimana melakukannya, yakni dengan memberi kepastian hukum terhadap aspek keselamatan, keamanan, kenyamanan, kesetaraan, keterjangkauan, dan keteraturan 
serta menampung perkembangan kebutuhan masyarakat dalam penyelenggaraan angkutan umum, dan memberikan perlindungan dan penegakan hukum bagi masyarakat. PM 108 Tahun 2017 diterbitkan oleh Kementerian Perhubungan menyusul tindak lanjut dari putusan Mahkamah Agung No. 37/P.HUM/2017 tanggal 20 Juni 2017 yang mencabut sebagian ketentuan dalam PM 26 Tahun 2017. Dengan demikian PM 108 Tahun 2017 merupakan peraturan terbaru dengan mencabut PM 26 Tahun 2017. PM 108 Tahun 2017. Pada dasarnya, aturan angkutan sewa online dalam PM 108 Tahun 2017 sama sekali tidak mempermasalahkan penggunaan teknologi. Sebaliknya, dengan peraturan ini, angkutan sewa online yang menggunakan aplikasi berbasis teknologi informasi telah diakomodir agar dapat beroperasi sesuai dengan peraturan perundang-undangan di bidang transportasi.

Dengan adanya kemajuan teknologi kita tidak bisa membatasi ruang gerak dari inovasi tersebut. Akan tetapi karena kita tinggal di negara hukum maka sudah sepantasnya pemerintah mengatur transportasi online maupun tidak online dengan cara yang sudah ditempuh yakni dengan mengeluarkan peraturan peraturan yang terkait dengan transportasi online. Sehingga diharapkan ada keseimbangan antara peraturan dengan perkembangan teknologi dengan tentunya mengedepankan kebutuhan masyarakat luas. Hanya penulis melihat pada awalnya saja terjadi kekakuan pada pemerintah dalam menetapkan aturan sehingga terlihat dengan dianulir oleh MA beberapa pasal dalam peraturan yang sudah dibuat oleh permenhub. Sebenarnya jika kita pandang dari sisi efektivitas dari suatu program atau kebijakan pemrintah, dengan adanya transportasi online ini membantu pemerintah menjawab permasalan masyarakat terkait transportasi yang ada. Aturan yang pemerintah pusat dibuat tentu ditaati pemerintah daerah hanya disayangkan jika perkembangan teknologi tidak dibarengi dengan aturan yang lebih baik dan lebih melihat sisi efektivitas kebijakan publik.

Kemudian dari sisi lain, dengan adanya transportasi online ini ada beberapa pihak yang dalam hal ini pengusaha transportasi online sebaiknya juga menaati dan melihat apakah sudah sesuai dengan peraturan umum yang pemerintah buat. Seperti misalnya sebelum adanya peraturan baru Permenhub Nomor 108 Tahun 2017, sebelumnya Undang-Undang Nomor 22 
Tahun 2009 tentang Tentang. Lalu Lintas Dan Angkutan Jalan yang wajib mendasari ruang gerak usaha tersebut.

\section{PENUTUP}

Kebijakan merupakan jalan keluar yang diambil oleh pemerintah guna menyelesaikan masalah publik. Evaluasi perlu dilakukan karena mengingat perlunya revisi disetiap peraturan guna melihat apa yang dibutuhkan oleh masyarakat. Dengan berkembangnya teknologi dan kemajuan zaman dalam hal transportasi maka sebaiknya pemerintah mendukung dengan mengeluarkan aturan/kebijakan yang berpihak kepada masyarakat luas dan tentu tidak melanggar Undang-Undang NO. 22 Tahun 2009 Tentang Lalu Lintas dan Angkutan Jalan.

\section{DAFTAR PUSTAKA}

Agustino, Leo. 2012. Dasar-Dasar Kebijakan Publik. CV. Alfabeta: Jakarta. Danim. 2004. Sumber Daya Manusia. Jakarta: Grafindo Persada

Anderson, L dan Krathwohl, D. (2010). Kerangka Landasan Untuk Pembelajaran, Pengajaran dan Asesmen Revisi Taksonomi
Pendidikan Bloom. Yogyakarta : Pustaka Pelajar

Nurudin. 2004. Perkembangan Teknologi Komunikasi. Raja Grafindo Persada.

Suharto, Edi. (2008), Kebijakan Sosial sebagai Kebijakan Publik. Bandung:

Alfabeta

William $N$ Dunn. Pengantar Analisis Kebijakan Publik Ed. 2 - dari Buku Beta Jogja : bukubeta

Sumber Lain:

Undang-Undang Nomor 22 Tahun 2009

Tentang Lalu Lintas dan Angkutan Jalan

Peraturan Kementerian Perhubungan Nomor 32 Tahun 2016 tentang

Peraturan Kementerian Perhubungan Nomor 26 Tahun 2017 tentang Revisi Aturan Angkutan Sewa Online Diberlakukan dengan Masa Transisi Nomor 32 Tahun 2016

Peraturan Kementerian Perhubungan Nomor 108 Tahun 2017

http://ypki.o.id (data tentang survey konsumen trasnportasi online tahun 2017) 
